\title{
The European Arrest Warrant in Designer Drugs Cases. With or Without Verification of Double Criminality?
}

\author{
Dominik Zając ${ }^{1}$ (D)
}

Accepted: 19 April 2021

(C) The Author(s) 2021

\begin{abstract}
The cross-border character of the designer drugs crimes forced the UE countries to cooperate in criminal prosecution. At first sight, in European Union law, there are proper instruments to enforce such cooperation. The Framework Decision on the European Arrest Warrant introduces the model of cross-border prosecution and abandons the requirement of double criminality in case of the group of the 32 crimes, listed in the Article 2 (2) of the FD EAW. The question is whether such a simple variant of EAW (without checking double criminality) may be enforced in designer drug cases. The work presents an argumentation that the normative meaning of Article 2 (2) of the FD EAW has to be established under European and international law. As long as a particular new drug is not internationally recognized as 'psychotropic substance' or 'narcotic drug', its trafficking cannot be treated as one of the 32 crimes, mentioned above.
\end{abstract}

Keywords European Arrest Warrant · Designer drugs crimes · Double criminality

\section{Introduction}

Let us imagine the following situation: Mr. John Doe, a citizen of Great Britain, produces designer drugs and sells them to Polish consumers via the Internet. The drugs are transported by several European couriers. Polish officials obtain information aboutthe transaction and decide to charge Mr. Doe for the crime of drug trafficking, as described in Article 56 of the Polish Act on counteracting drug addiction. ${ }^{1}$ For sentencing, the perpetrator's physical presence in Poland is required. Unfortunately, Mr. Doe hides in France. Because of this, the prosecutor starts the procedure of the European Arrest Warrant (hereafter the

\footnotetext{
1 Article 56 of the Act of June 6, 1997 On Counteracting Drug Addiction, Journal of Laws 2005 No. 179 item 1485, with amendments: 'Whoever, contrary to the provisions of art. 33-35, art. 37, art. 40 and art. 40a, places narcotic drugs, psychotropic substances, poppy straw or new psychoactive substances on the market, or participates in such turnover, is subject to the penalty of deprivation of liberty for between 6 months and 8 year'.
}

Dominik Zając

d.zajac@uj.edu.pl

1 Department of Criminal Law, Jagiellonian University, Krakow, Poland 
EAW) The question is, 'Can France extradite Mr. Doe without establishing the double criminality of his act under Article 2 (2) of the EAW Framework Decision?'.

The article analyses the prerequisites for using a simple variant of the EAW, as described in Article 2 (2) of the EAW Framework Decision (hereafter the FD EAW), ${ }^{2}$ on conventional crime cases (Vierucci, 2004, p. 275; Mackarel, 2007, p. 40). The discussed problem is of a universal character and trafficking serves only as an illustration here.

The article consists of four parts. The first briefly characterises the EAW procedure, focusing especially on its simple variant, as described in Article 2 (2) of the FD EAW. This leads to a discussion on the role of the Issuing and the Surrendering State in the application's process of EAW procedure. The next step enquires into the method of interpretation of the normative content of Article 2 (2) of the FD EAW, with a special focus on the list of the 32 crimes. The last part presents the application of this method to drug cases.

\section{European Arrest Warrant as a Simple Way to Extradite}

The EAW procedure was introduced into the European legal system in 2003. Theprimary goal of the regulation is to improve the prosecution of crimes committed within the territory of the European Union. Along with the free movement of people, there is also the free movement of criminals. Because of that, the EU decided to simplify the extradition process between Member States (Sliedregt, 2007, p. 244; Spencer, 2004, p. 202; Report, 2011). Given the topic of this work, there is no need to analyse all aspects of the EAW in this article. ${ }^{3}$ From the perspective of designer drug crimes, the most important thing is that the FD EAW describes two variants of the procedure. In the first, which serves as a general principle, the EAW requires the establishment of double criminality. This means that before its execution, the Surrendering State has to verify whether the act of the perpetrator is penalized both under the law of the Issuing and the Surrendering state. The second variant of the procedure drops this requirement. If the request concerns an act that constitutes one of the specific crimes listed in Art. 2 (2) of the FD EAW, the Surrendering State cannot verify the double criminality of the act. Because of that, this variant is called 'simple' (Ambos, 2018, p. 435; Gilmore 2002, p. 146; Plachta, 2003, p. 186; Perignon \& Dauce, 2007, p. 206; Klimek, 2017, p. 502; Sliedregt, 2007, p. 248). ${ }^{4}$

The requirement of double criminality is a traditional element of extradition regulations. It forces the executing state to check whether an act of a perpetrator is punishable under the laws of both cooperating states (in this way, each country tries to protect the freedom of individuals and its own sovereignty-lack of double criminality is an argument against extradition) (Lagodny, 2005, pp. 1-4; Jareborg, 1989, p. 43-56, 107; Coutts, 1984, pp. 93-101; Gardocki, 1993, pp. 288-296; Hudson, 1934, pp. 274-306; Mullan, 1997, pp. 17-19; Grundza case, C-289/15, ECLI:EU:C:2017:4).

\footnotetext{
${ }^{2}$ Council Framework Decision of 13 June 2002 on the European arrest warrant and the surrender procedures between Member States, 2002/584/JHA.

${ }^{3}$ In this field, see inter alia: European Commission, 2017; Ambos, 2018, pp. 432-453; Klimek, 2015, pp. 376; Blekxtoon \& van Ballegooij, 2005; Sliedregt, 2007, p. 244; Perignon \& Dauce, 2007, pp. 203-204; Bapuly, 2009, pp. 8-15; Plachta, 2003 pp. 178-194; Mitsilegas, 2009, p. 120-122; Braum, 2018, p. 1351; Kettunen, 2020, pp. 278; Quattrocolo \& Ruggeri, 2019, pp. 752; Herlin-Karnell, 2012, pp. 285; Colson \& Field, 2016, pp. 294; Herlin-Karnell, 2016, p. 291-317.

${ }^{4}$ Sliedregt indicates: 'mutual trust has been the reason for abolishing the dual criminality rule for a number of crimes and for removing the executive from the decision-making process'.
} 
The possibility of applying a simple variant of the EAW is of crucial importance for the efficiency of the EAW procedure. A lot of time, money and effort are engaged in verifying the double criminality requirement. It is a consequence of making a parallel between the two legal systems. To avoid these obstacles, a requesting country tries to use opportunity described in Article 2(2) of the EAW Framework Decision as often as possible. In this way, the EAW procedure becomes simpler and cheaper to enforce (Wyngaert, 1989, p. 94, Ambos, 2018, p. 434; Nohlen, 2008, p. 154; Perignon \& Dauce, 2007, p. 209; Spencer, 2004 , p. 202). Such a simpler procedure is also the first instrument of mutual recognition in the area of criminal procedure. The meaning of this construction goes beyond direct, pragmatic goals - it creates a ground for further harmonisation of criminal law within the European Union (Ralli, 2017, pp. 4-6; Colson \& Field, 2016, p. 199-220; Mancano, 2016, pp. 215-238).

Article 2 (2) of the FD EAW describes the prerequisites for application of a simple variant of the EAW. Amongst them, 32 types of crimes are indicated, for which the surrender of a perpetrator does not require a verification of double criminality (Klimek, 2017, p. 503; Bapuly, 2009, p.12; Kettunen, 2020, p. 181). The list includes two kinds of drug crimes. The provision stipulates: 'The following offences, if they are punishable in the issuing Member State by a custodial sentence or a detention order for a maximum period of at least 3 years and as they are defined by the law of the issuing Member State, shall, under the terms of this Framework Decision and without verification of the double criminality of the act, give rise to surrender pursuant to a European arrest warrant: [...] - illicit trafficking in narcotic drugs and psychotropic substances'.

However, the list does not contain a full description of all elements of the indicated prohibited acts. Because of that, a serious problem of interpretation arises. ${ }^{5}$ Such terms as 'narcotic drugs' or 'psychotropic substances' do not have the same precise meaning in particular legal systems of all EU Member States. The results are complications of the application of the EAW solution.

To answer the question under what circumstances it is possible to use a simple variant of the EAW, we need to consider two aspects of the problem: first, the roles of the Issuing and Surrendering States in the application of this variant; second, the interpretation of normative meaning of the list of the 32 crimes included in Article 2 (2) of the EAW Framework Decision.

\section{The Two Main Actors in the EAW Procedure}

In the EAW procedure, there are two cooperating states. The first one, called the Issuing State, prepares the EAW and sends it to the second one, which is called the Surrendering (Executing) State (Ambos, 2018, p. 433; Bapuly, 2009, p. 14).

The issuing Member State decides to prosecute for a particular behaviour under its domestic criminal law. The charges contain the description of the act of the perpetrator and indicate the accurate article of the domestic criminal code (Klimek, 2017, p. 557). In this phase, the Issuing State verifies whether a prosecuted act is punishable 'by a custodial sentence or a detention order for a maximum period of at least 3 years' (one of the

\footnotetext{
${ }^{5}$ In this field, see inter alia: Statement of the Advocaten voor de Wereld, ECJ Case C-303/05, 3 May 2007; Klimek, 2017, p. 506; Perignon \& Dauce, 2007, p. 207; Spencer, 2004, p. 209; Bapuly, 2009, p. 12; Plachta, 2003, p. 190; Ambos, 2005, p. 175).
} 
prerequisites defined in Art. 2 (2) of the FD EAW). In this form, they are put into the EAW. Next, the content of the charges is compared with the list of the 32 crimes contained in the Art. 2 (2) (European Commission, 2017, p. 17; Herlin-Karnell, 2012, p. 178). If the court of the Issuing State decides that the prosecuted act is one of these crimes, it issues the EAW via the simple procedure without verification of double criminality (the EAW form has a special place for indicating such circumstances - this is included in the Appendix to the FD EAW).

The FD EAW forces the Surrendering State to cooperate in executing the EAW without checking double criminality, but only if the prosecuted act is a crime listed in Article 2 (2) of the FD EAW. As a principle, the Surrendering State is able to verify the double criminality of the act that is described in the EAW. In this way, the Surrendering State has the chance to protect individuals from being prosecuted for acts that are not treated as crimes under its domestic law. Such power is derived from the sovereignty of the state (Wyngaert, 1989, p. 52; Sliedregt, 2007, p. 252; Fennelly, 2007, p 522; Nohlen, 2008, p. 155). No state is obliged to extradite the individual until such an obligation is provided by international law.

Under Article 2 (2) of the FD EAW, the Surrendering State cannot verify the requirement of double criminality. Instead, it can verify whether a particular act can be treated as one of the crimes mentioned in the above list. The list of 32 crimes replaces the requirement of double criminality, which is an instrument in favour of the Surrendering State. From this point of view, the Surrendering State is able to check whether the act of the perpetrator, as described in the EAW, belongs to this group. The Surrendering State verifies the EAW not from the perspective of its domestic law but from the point of view of the criteria described in the FD EAW. It uses the same point of reference as does the Issuing State. There is still a double check, but one that is based on the same group of premises (this issue is discussed in the course of further considerations).

This does not contradict the principle of mutual recognition mentioned in point 2 of the Preamble of the FD EAW. ${ }^{6}$ The above solution indicates only the prerequisite for this mechanism. The mutual recognition is a general principle that has to be connected with detailed premises described in a particular legal institution (here, the EAW). The criterion of belonging to the group of 32 crimes has to be taken as such a prerequisite for applying the simplified EAW procedure.

FD EAW provides the entitlement to such a verification. As we can read in the Handbook on How to Issue and Execute a European Arrest Warrant, 'the executing judicial authority should check whether any of the offences have been determined by the issuing judicial authority as belonging to one of the 32 categories of offences listed in Article 2(2) of the Framework Decision on EAW' (European Commission, 2017, p. 39). If they do not belong, it may open the door to refusing EAW execution under the Article 4 (1) and Article 2(4) of the FD EAW.

The FD EAW provides two articles, which establish the ground for refusing the execution of EAW. First of all, Article 3 of the FD EAW describes 'Grounds for mandatory non-execution of the European arrest warrant'. It refers to such construction as ne bis in idem principle or amnesty and has unconditional character. Here the execution of EAW is blocked even before verification occurrence of the criteria described in Article 2(2) of the

\footnotetext{
${ }^{6}$ Preamble of the FD EAW, point 2: 'The programme of measures to implement the principle of mutual recognition of criminal decisions envisaged in point 37 of the Tampere European Council Conclusions and adopted by the Council on 30 November 2000(3), addresses the matter of mutual enforcement of arrest warrants'. See also: Gilmore, 2002, p. 144; Öberg, 2020, p. 33-62; Ouwerkerk, 2018, p. 103-109.
} 
FD EAW (Herlin-Karnell, 2012, p. 40, European Commission, 2017, p. 40-45; Klimek, 2015, p. 150-166).

From the perspective of the main topic, the crucial meaning has Article 4 of the FD EAW, titled 'Grounds for optional non-execution of the European arrest warrant', with special focus on paragraph (1) of this provision. According to it, the Surrendering State can refuse to execute the EAW: 'If, in one of the cases referred to in Article 2(4), the act on which the European arrest warrant is based does not constitute an offence under the law of the executing Member State; however, in relation to taxes or duties, customs and exchange, execution of the European arrest warrant shall not be refused on the ground that the law of the executing Member State does not impose the same kind of tax or duty or does not contain the same type of rules as regards taxes, duties and customs and exchange regulations as the law of the issuing Member State' (Gilmore 2002, p. 146; European Commission, 2017, p. 42-43; Klimek, 2015, p.159-163). Article 2(4) of the FD EAW provides the requirement of double criminality: 'for offences other than those covered by paragraph 2'.

To verify the above circumstances, the Surrendering State has to be able to verify whether the particular behaviour has to be treated as a crime described in Article 2 (2) or Article 2 (4) of the FD EAW. Denying the entitlement to such a verification by the Surrendering State leads to unacceptable consequences.

First, the Surrendering State is reduced to the role of an executor of the order of the the foreign state official in a field of interpretation of European regulations (Heard \& Mansell, 2011, p. 133). Second, the EAW decision does not provide any requirements for the Issuing State in the field of appeal. This means that the individual may often question the basis of the EAW only before the officials of the Surrendering State. Such a solution is provided in point 8 of the Preamble of the EAW Framework Decision, which stipulates: 'Decisions on the execution of the European arrest warrant must be subject to sufficient controls, which means that a judicial authority of the Member State where the requested person has been arrested will have to take the decision on his or her surrender'. (Fennelly, 2007, p. 533). The procedure conducted by the Surrendering State is the only one in which the individual can question the prerequisite described in Article 2 (2) of the FD EAW (Ambos, 2018, p. 435). Third, there is quite a large risk that the courts of the issuing Member State will indicate any type of act as a crime listed in Article 2 (2) of the FD EAW for the sole purpose of simplifying the procedure. This problem will be discussed in the next part of the work.

Considering these facts, we have to conclude that both the Issuing and the Surrendering Member State has to be entitled to verification of whether the requirements are fulfilled in the particular cases, as described in Article 2 (2) of the FD EAW. The Issuing State formulates the hypothesis that a particular behaviour, penalized under its domestic regulations, has to be treated as one of the 32 types of crimes described in the commented provision. The Surrendering State is empowered to verify such a hypothesis in the course of the EAW procedure, under Article 4 of the FD EAW.

\section{Establishing the Constituent Elements of the Crimes Listed in Article 2 (2) of the FD EAW}

The next question is what criterion should be used in the process of assessment of the perpetrator's act from the perspective of Article 2 (2) of the FD EAW. To answer whether a particular behaviour constitutes one of the 32 crimes described in the provision, we have to 
establish its constituent elements. This can be done in two different ways: by considering the domestic law of the Issuing State or by looking at the regulations of international law. ${ }^{7}$

\section{Domestic Regulations of the Issuing State}

It is possible to compare an article of the domestic criminal code with the 'title' of a crime listed in Article 2 (2) of the FD EAW. In this way, we can indicate that a particular article of the domestic legal system penalizes such behaviour, which can be treated, for example, as 'illicit trafficking of narcotic drugs'. In this approach, the court of the Issuing State makes an interpretative decision. The 'titles' of the 32 crimes are connected with domestic types of penalized behaviour. Such an interpretation is made without considering any regulations of international law. Normative meanings of 'titles' are established by domestic courts on the grounds of the internal legal system.

Such a method of interpretation is suggested by the CJEU and accepted also within the doctrine (Klimek, 2017, p. 504; Mitsilegas, 2009, pp. 138-142). In the judgement of the CJEU C-303/05, 3 May 2007, ${ }^{8}$ the Court indicated that "the actual definition of those offences and the penalties applicable are those which follow from the law of 'the issuing Member State'. The Framework Decision does not seek to harmonise the criminal offences in question in respect of their constituent elements or of the penalties which they attract. Accordingly, while Article 2 (2) of the Framework Decision dispenses with verification of double criminality for the categories of offences mentioned therein, the definition of those offences and of the penalties applicable continue to be matters determined by the law of the issuing Member State". 9

The above solution has serious disadvantages that, in my opinion, should cause its rejection. ${ }^{10}$

First, such an interpretation creates the same problem as the requirement of double criminality. The Surrendering Court has to interpret the foreign legal system to verify the conditions described in the FD EAW (Ambos, 2018, p. 436).

This also leads to another untenable situation. The Issuing State assesses whether some behaviour, treated as a crime under its national criminal law, is the same as one of the crimes listed in a European legal act. However, the normative meaning of the listed crimes is taken from the same national criminal law. In this situation, the comparison is made between two elements of the same normative meaning. There is no opportunity to conduct a proper verification: the subject of assessment is identical to the criterion of assessment. This leads to an idem per idem mistake. Meanwhile, the conditions for the application

\footnotetext{
7 Under the Article 2 (2), it is not possible to refer to legal system of Surrendering Member State in course of verification the normative meaning of the constituent elements of crimes listed in this provision. It does not mention law of surrendering state. What is more, such verification would mean introducing the requirement of dual criminality.

8 Judgment of the Court of Justice of 3 May 2007, Advocaten voor de Wereld, C-303/05, ECLI:EU:C:2007:261, paragraphs 52 to 53; see also: Opinion of Mr Advocate General Ruiz-Jarabo Colomer delivered on 12 September 2006, ECLI:EU:C:2006:552, paragraphs 83 to 95.

9 In this field, see also Geyer, 2007, p. 149-161; Sliedregt, 2007, p. 250; Fennelly, 2007, p. 532-533; Klimek, 2017, pp. 555; Sarmieto, 2008, pp.175-177; Kettunen, 2020, p. 25; Report, 2002, p. 12; Case law, 2020; Judgment of the Court of Justice of 3 March 2020, X, C-717/18, ECLI:EU:C:2020:142; Order of the Court of Justice of 25 September 2015, A, C-463/15, ECLI:EU:C:2015:634.

10 The judgement was also criticised in doctrine. See inter alia: Ambos, 2018, p. 436, who wrote: "Unfortunately, this judgment contains hardly any substance: on the one hand, the empty claim of a 'high degree of trust and solidarity between Member States' is touted, although it is increasingly becoming, as the expands further and further, a mere Brussels of Luxembourg phantasmagoria".
} 
of the simple variant of the EAW are described both in the domestic criminal law of the Member State and the Framework Decision.

Under the solution proposed by the CJEU, the Surrendering State loses any opportunity to check whether a particular behaviour in fact constitutes a crime listed in Article 2 (2) of the FD EAW. Without knowledge of the legal system of the Issuing State, the Surrendering State has no opportunity to revise the EAW Decision (Mansell, 2012, p. 44; Ambos, 2018, p. 435-436).

It has to be emphasised that this is not a problem of checking double criminality. The issue in question is concerned with the verification of grounds for applying the simple variant of the EAW. Taking seriously the Article 2(2) of the EAW FD, such verification should be treated as something completely different from checking double criminality. The purpose of the discussed provision is to avoid this requirement, but the interpretation proposed by the CJEU leads to the creation of the somehow 'undercover double criminality test'.

In this approach, the terms used in Article 2 (2) of the FD EAW do not have a universal meaning. This meaning is given ad hoc by the decision of the issuing Member State. The court interprets, for example, the phrase 'illicit trafficking of narcotic drugs' by taking the domestic legal system as a point of reference. In this way, the same legal term derived from the same legal act (for example: 'illicit trafficking of narcotic drugs') gains a different normative meaning, depending on who is the interpreter (Klimek, 2017, p. 558).

To explain this aspect of the problem, we can use an example. Before 2018, in the Polish criminal law, there were no drug offenses related to designer drugs. Polish anti-drug regulations did not statute any criminal responsibility for trafficking or producing designer drugs. At the same time, Polish prosecutors started to treat some special cases of research chemicals trafficking as a crime of common endangerment (Article $165 \S 1$ point 2 of the Polish Criminal Code ${ }^{11}$ ). The prosecution was conducted not because of the psychoactive features of the designer drugs, but because of the dangers to life and health that such substances may cause.

As we have said, to issue the EAW under Article 2 (2), it is necessary to indicate that the act of the perpetrator constitutes 'illicit trafficking of narcotic drugs or psychotropic substances'. Let us imagine Polish officials indicate on the EAW form the perpetrator committed illicit trafficking of designer drugs, which is treated as 'illicit drug trafficking' under the Polish criminal law. Of course, this is not true. Such an act is not a drug offense under Polish law. It should be treated as a different crime. In this situation, there are no grounds for using a simple variant of the EAW because Article 165 of the Polish Criminal Code does not refer to any drug crime. However, according to the approach forced by the CJEU, there is also no possibility to verify such a situation by the Surrendering State. In this case, the main issue is connected with the principle of legality (Peristeridou 2015, p. 360; Gallant 2009, p. 303). Without procedural instruments of verification, however, there will be no possibility to block the enforcement of a simple variant of the EAW in controversial situations. The Surrendering State would be in a fact forced to cooperate without procedural possibility of a refusal.

Looking at all of these disadvantages, we have to reject the above method of interpretation.

11 Article $165 \S 1$ point 2 of The Act of June 6, 1997Criminal Code, Journal of Laws 1997 No. 88 item 553: 'Whoever brings about danger to life and health of multiple persons or property of substantial extent: [... 2) by producing or introducing into market substances that are harmful to health, food products or other products of general use, or pharmaceutics not meeting mandatory quality standards, [...] is subject to the penalty of deprivation of liberty for between 6 months and 8 years'.- translation: Wojtaszczyk, Wróbel, Zontek 2014, pp. 155-156. 


\section{International Regulations}

To enforce Article 2 (2) of the FD EAW properly, we need to use a different method to interpret the catalogue of crimes. The court of the Issuing State should compare an act (a behaviour of perpetrator that can be treated as a crime under the domestic law of the Issuing State) with the constituent element of crimes described in Article 2 (2), whose normative meanings have to be derived from international law: agreements, conventions, judgements of international tribunals (Klimek, 2017, p. 505; Fletcher et al., 2008, pp. 114-115).

Broadly understood, international law provides the minimal standards of penalization and human rights protection that were fulfilled by the Member States even before setting the EU law $^{12}$ (Fennelly, 2007, p. 520, Zając, 2019, p. 28). In this perspective, EU law can be seen as a separated branch of the law of local character, located between domestic legal systems and law recognized by the general (non-local) international community. From the one side, it obliges the state to implement or execute laws established by the organs of the European Union. From the other, it is under the influence of general international law: customs, UN conventions, etc. (Ziegler, 2015, p. 2; van Rossem, 2009, p. 183-227). Conventions-but also the law of the United Nations or custom ${ }^{13}$ - are obliging the states to penalize certain kinds of behaviour.

These sources of international norms have their own and, in many cases, quite clear meaning. By comparing the constituent element of crime derived from the international law, EU law and provisions of the domestic legal systems, we realize domestic regulations contain these supranational elements and more.

This means that often we can establish a minimum catalogue of the constituent elements of crimes, as described in Article 2 (2) of the FD EAW, deriving them from international law. Such a catalogue is universal and not rooted in the domestic legal system of a foreign state. The application of the discussed solution is always possible in cases of conventional crimes, such as illicit trafficking of drugs (the example of such an interpretation is discussed in detail below).

In addition, in this approach, the central point of verification is the behaviour of the perpetrator. Theoretically, this may lead to a situation where, from the perspective of domestic regulations, the particular act is not treated as, for example, illicit drug trafficking but as a crime of common endangerment (as stated above). From the perspective of the discussed solution, there is no obstacle to enforcing the EAW under Article 2 (2). We need to assess the behaviour from the perspective of international law, not the similarity between international and domestic norms.

Thus, the assessment of behaviour has to be made from two perspectives.

First, to formulate the charges, a court of the Issuing State has to use the domestic provisions. Their semantic content, not the normative one, may overlap with Article 2 (2) of the FD EAW.

In the second step, a court of the Issuing State has to assess the behaviour from the perspective of the independent criteria (constituent elements of the crime) described in Article 2 (2) of

\footnotetext{
12 'Europe as the continent of humane values, the Magna Carta, the Bill of Rights, the French Revolution and the fall of the Berlin Wall; the continent of liberty, solidarity and above all diversity, meaning respect for others' languages, cultures and traditions. The European Union's one boundary is democracy and human rights. The Union is open only to countries which uphold basic values such as free elections, respect for minorities and respect for the rule of law'.-Presidency conclusions, 2001, p. 20.

13 Article 38 of the Statute of the ICJ which provides for a list of sources of international law in general, stipulates: '1. The Court, whose function is to decide in accordance with international law such disputes as are submitted to it, shall apply: a. international conventions, whether general or particular, establishing rules expressly recognized by the contesting states; b. international custom, as evidence of a general practice accepted as law; c. the general principles of law recognized by civilised nations; $d$. subject to the provisions of Article 59, judicial decisions and the teachings of the most highly qualified publicists of the various nations, as subsidiary means for the determination of rules of law. 2 . This provision shall not prejudice the power of the Court to decide a case ex aequo et bono, if the parties agree thereto'.
} 
the FD EAW. Such criteria have to be established based on standards derived from European and international law. Only in this way can we provide stable and universal content of Article 2 (2) of the FD EAW. To use a simple variant of the EAW, the court of the Surrendering State has to verify whether the act of the perpetrator can be treated as such a crime under international regulations.

\section{'Illicit Trafficking of Narcotic Drugs and Psychotropic Substances' as a Conventional Crime}

The applicability of the proposed solution should now be verified with the example of drug trafficking. Let us return to the Mr. Doe situation. From the perspective sketched in the introduction, the crucial question is: 'Is the production and selling of designer drugs one of the crimes listed in Article 2 of the FD EAW'. To answer this question, we analysed the normative content of the list described as 'illicit trafficking in narcotic drugs and psychotropic substances'.

We had to establish the legal meaning of three elements mentioned in Article 2.2 of the FD EAW: (1) illicit trafficking, (2) narcotic drugs and (3) psychotropic substances. Further considerations focus on the establishment of meaning of these three terms under European and international law, taking into account that the regulations of criminal law have to be strictly interpreted. ${ }^{14}$

Amongst the European legal acts, two refer to the problem of drug trafficking. The first is the Council Framework Decision 2004/757/Jha of 25 October 2004. The second one is the Directive (EU) 2017/2103 of the European Parliament and of the Council of 15 November 2017, which modifies the above Council Framework Decision.

Both refer to the three United Nations conventions: the UN Convention on Psychotropic Substances, 1971; the Single Convention on Narcotic Drugs, 1961 and the United Nations Convention against Illicit Traffic in Narcotic Drugs and Psychotropic Substances, $1988 .{ }^{15}$ This means that in the field of drug crimes, there is an overlap in two branches of international law. To establish the meaning of the constituent elements of crime, we have to consider both of them (Klimek, 2017, p. 520).

\section{Illicit Trafficking}

The EU law does not define 'illicit trafficking'. The Council Framework Decision 2004/757/Jha uses the term but does not explain the exact meaning. In Article 2 of the Decision, titled 'Crimes linked to trafficking in drugs and precursors', we can see the list of behaviours that are only connected with trafficking, but do not has to constitute this kind of behaviour.. ${ }^{16}$ Directive (EU) 2017/2103 of the European Parliament and the Council also

\footnotetext{
14 Similar analysis was presented by L. Klimek, but without taking into account the precise, normative meaning of the phrase: narcotic drugs and psychotropic substances-Klimek, 2017, pp. 519-525.

15 The above act does not contain autonomic definitions of 'narcotic drugs' and 'psychotropic substances', but it defines 'illicit traffic'.

16 Article 2 of the Council Framework Decision 2004/757/Jha, titled: Crimes linked to trafficking in drugs and precursors stipulates: ' 1 . Each Member State shall take the necessary measures to ensure that the following intentional conduct when committed without right is punishable: (a) the production, manufacture, extraction, preparation, offering, offering for sale, distribution, sale, delivery on any terms whatsoever, brokerage, dispatch, dispatch in transit, transport, importation or exportation of drugs; (b) the cultivation of opium poppy, coca bush or cannabis plant; (c) the possession or purchase of drugs with a view to conducting one of the activities listed in (a); (d) the manufacture, transport or distribution of precursors, knowing that they are to be used in or for the illicit production or manufacture of drugs. 2. The conduct described in paragraph 1 shall not be included in the scope of this Framework Decision when it is committed by its perpetrators exclusively for their own personal consumption as defined by national law'.
} 
does not focus on the description of particular criminal actions, but only modifies the definition of a 'drug' (see further considerations).

To establish the normative meaning of 'illicit trafficking', we have to look at the conventions of the United Nations.

According to Article 1 letter $(\mathrm{m})$ of the UN Convention on Psychotropic Substances, "Illicit traffic' means manufacture of or trafficking in psychotropic substances contrary to the provisions of this Convention." Under Article 1 letter (1) of the Single Convention on Narcotic Drugs, 1961, “'Illicit traffic' means cultivation or trafficking in drugs contrary to the provisions of this Convention". Both of these definitions are useful to a limited extent. They do not explain in a precise way how to understand 'trafficking'.

The most comprehensive definition of 'illicit traffic' is provided in Article 1 letter $(\mathrm{m})^{17}$ in connection with Article 3 paragraphs 1 and $2^{18}$ of the United Nations Convention against Illicit Traffic in Narcotic Drugs and Psychotropic Substances, Vienna, 20 December 1988. According to it, 'illicit traffic' is not only the 'production' or 'offering', but even the 'possession or purchase of any narcotic drug or psychotropic substance' for the purposes of such an offering.

17 Article 1 letter $(\mathrm{m})$ of the United Nations Convention against Illicit Traffic in Narcotic Drugs and Psychotropic Substances, Vienna, 20 December 1988 stipulates: ' $>>$ Illicit traffic $<<$ means the offences set forth in article 3, paragraphs 1 and 2, of this Convention'.

18 Article 3 of the United Nations Convention against Illicit Traffic in Narcotic Drugs and Psychotropic Substances, Vienna, 20 December 1988 stipulates: '1. Each Party shall adopt such measures as may be necessary to establish as criminal offences under its domestic law, when committed intentionally: (a) (i) the production, manufacture, extraction; preparation, offering, offering for sale, distribution, sale, delivery on any terms whatsoever, brokerage, dispatch, dispatch in transit, transport, importation or exportation of any narcotic drug of any psychotropic substance contrary to the provisions of the 1961 Convention, the 1961 Convention as amended or the 1971 Convention; (ii) the cultivation of opium poppy, coca bush or cannabis plant for the purpose of the production of narcotic drugs contrary to the provisions of the 1961 Convention and the 1961 Convention as amended; (iii) the possession or purchase of any narcotic drug or psychotropic substance for the purpose of any of the activities enumerated in (i) above; (iv) the manufacture, transport or distribution of equipment, materials or of substances listed in Table I and Table II, knowing that they are to be used in or for the illicit cultivation, production or manufacture of narcotic drugs or psychotropic substances; (v) the organization, management or financing of any of the offences enumerated in (i), (ii), (iii) or (iv) above; (b) (i) the conversion or transfer of property, knowing that such property is derived from any offence or offences established in accordance with subparagraph (a) of this paragraph, or from an act of participation in such offence or offences, for the purpose of concealing or disguising the illicit origin of the property or of assisting any person who is involved in the commission of such an offence or offences to evade the legal consequences of his actions; (ii) the concealment or disguise of the true nature, source, location, disposition, movement, rights with respect to or ownership of property, knowing that such property is derived from an offence or offences established in accordance with subparagraph (a) of this paragraph or from an act of participation in such an offence or offences; (c) subject to its constitutional principles and the basic concepts of its legal system: (i) the acquisition, possession or use of property, knowing, at the time of receipt, that such property was derived from an offence or offences established in accordance with subparagraph (a) of this paragraph or from an act of participation in such offence or offences; (ii) the possession of equipment or materials or substances listed in Table I and Table II, knowing that they are being or are to be used in or for the illicit cultivation, production or (iii) publicly inciting or inducing others, by any means, to commit any of the offences established in accordance with this article or to use narcotic drugs or psychotropic substances illicitly; (iv) participation in, association or conspiracy to commit, attempts to commit and aiding, abetting, facilitating and counselling the commission of any of the offences established in accordance with this article. 2. Subject to its constitutional principles and the basic concepts of its legal system, each Party shall adopt such measures as may be necessary to establish as a criminal offence under its domestic law, when committed intentionally, the possession, purchase or cultivation of narcotic drugs or psychotropic substances for personal consumption contrary to the provisions of the 1961 Convention, the 1961 Convention as amended or the 1971 Convention'. 
In this context, the activity of Mr. John Doe may probably be treated as 'illicit trafficking' under international law. The question is whether we can assess it as trafficking of 'narcotic drugs' or 'psychotropic substances'.

\section{Narcotic Drugs and Psychotropic Substances}

Article 2 (2) of the FD EAW stipulates that the above-defined 'illicit trafficking' has to refer to 'narcotic drugs' and 'psychotropic substances'.

There is no doubt that they have to be treated as part of a broader category of drugs, which has an established and quite precise meaning under the EU law. According to the Article 1 letter (a) of the Directive (EU) 2017/2103, titled 'Amendments of Framework Decision 2004/757/JHA', 'drug' means any of the following: (a) a substance covered by the 1961 United Nations Single Convention on Narcotic Drugs, as amended by the 1972 Protocol, or by the 1971 United Nations Convention on Psychotropic Substances; (b) any of the substances listed in the Annex. ${ }^{19}$ The above definition cannot be, however, useful in an interpretation of Article 2 of the EAW Decision for two reasons.

First, as we have seen, the European law does not define neither the term 'narcotic drugs' nor the term 'psychotropic substances', which are stated in the FD EAW. The above definition refers to the three elements-under the Directive (EU) 2017/2103 'drugs' that are substances covered by the two UN Conventions and the Annex. Therefore, 'narcotic drugs' and 'psychotropic substances' are connected only with UN law. Both terms were used only as a fragment of the definition, where it refers to the United Nations Conventions. This means that not all substances that have to be treated as a 'drug' under EU law can be termed 'narcotic drugs' or 'psychotropic substances'. In consequence, not all 'drugs' can be the subject of the 'illicit trafficking in narcotic drugs and psychotropic substances' mentioned in the FD EAW.

Second, neitherthe Directive of the European Parliament nor the Council Framework Decision contains any legal definitions that refer to Article 2 of the FD EAW. The FD EAW was created in 2003, several years prior to both EU legal acts that refer to drugs. ${ }^{20} \mathrm{At}$ that time, the law delivered by the United Nations was the only point of reference for drug cases. What is important is that the FD EAW has not been modified since 2003, even after introducing the European definition of a drug.

To establish what substances are 'narcotic drugs' or 'psychotropic substances' according to the binding law, we have to analyse the provision of the two above conventions of the United Nations. Both of them use a list of substances as a method of definition.

By 'narcotic drugs', we have to understand all substances listed in the Schedule I-IV of the 1961 United Nations Single Convention on Narcotic Drugs. According to Article 1, letter (e) of the 1971 United Nations Convention on Psychotropic Substances, "'psychotropic substance' means any substance, natural or synthetic or any natural material in Schedule I, II, III or IV".

This means that under international law, the terms 'narcotic drugs' and 'psychotropic substances' have a precise meaning. It is easy to verify whether a given substance produced or sold in a particular case is mentioned in one of the above schedules. Only under these circumstances can the perpetrator's behaviour be considered 'illicit trafficking narcotic drugs or psychotropic substances'. Such an interpretation entails serious consequences for the application of the procedure of the EAW.

\footnotetext{
19 Annex is a part of a Directive and it contains list of the 12 substances referred to in point (b) of point 1 of Article 1 of the Directive (EU) 2017/2103, inter alia: P-Methylthioamphetamine or MDMB.

${ }^{20}$ Council Framework Decision 2004/757/Jha-2004 and Directive (EU) 2017/2103 of the European Parliament and of the Council-2017.
} 


\section{Designer Drugs as Substances Beyond the Scope of Article 2 of the FD EAW}

In the case sketched at the beginning of the article, the perpetrator takes part in the trafficking of so-called 'designer drugs' or 'research chemicals'. Such substances are not, as a principle, mentioned in international conventions. The whole idea of designer drugs is based on one assumption: the creators of new drugs have to be one step ahead of legislators. They focus on synthesizing new types of substances that influence the central nervous system but that are not listed in international or even national lists of prohibited drugs (Stackhouse, 2012, p. 1105- 1137; Klimek, 2017, p. 524).

For this reason, the EU officials modified the definition of 'drug' under the abovementioned Directive (EU) 2017/2103 by adding the third element, namely the reference to the Annex. The Annex is in fact an official list of new drugs, similar to the Schedules that are attached to the UN Convention, but it has one great advantage over them. It can be easily supplemented by new substances, by the decision of the EU officials.

As we have seen, such a new definition is still not compatible with the FD EAW. It is not possible to use it in the Article 2 (2) of the FD EAW in a particular case (see the argumentation in the previous part of the work).

However, the lack of coherence between the EAW and European drug regulations is not a crucial problem in the commented case. The main issue is the method of definition. Let us assume the EAW Decision had been changed, and now, Article 2 refers to 'drug' with the meaning of the Directive (EU) 2017/2103. This does not entail any change in the situation of Mr. Doe. He produces substances that are not listed in the Annex. His act is still beyond the scope of the internationally recognized 'illicit trafficking of drugs'.

As a result, we have to conclude that in the case of designer drugs, it is not possible to use the simple variant of the EAW procedure. In all such cases, the Surrendering State has to check the requirement of double criminality.

Is this situation acceptable? Should we treat this as a 'bug in the law' and fix it or should we agree that in the case of designer drugs we need to abandon the simple way of investigating? To answer this question, we have to return to the previous part of this work. We have pointed out that crimes listed in Article 2 (2) of the FD EAW concern behaviours that are punishable under the domestic laws of each Member State. Such a situation does not occur in the case of trafficking of designer drugs. The only supranational consensus in this regard is provided by the abovementioned Appendix which does not have to be coherent with domestic regulations. Of course, each state can prohibit and punish the trafficking of different categories of new substances, but this is beyond the European consensus. Consequently, it is quite possible that some activities will be treated as a crime by one Member State, but not by another. Although such a situation is not in contradiction with the European Union regulation (Article 83 of TFEU ${ }^{21}$ does not force the Member States to the unification of criminal law norms), it may raises controversy in the context of Article 2 (2) of the EAW FD. If the simple variant of EAW is connected with the internationally recognizable definition of illicit trafficking of drugs, using it in cases beyond this definition remains in opposition to the main assumptions of the construction regulated in Article 2 (2) of the EAW FD.

\footnotetext{
21 Article 83 of the Consolidated version of the Treaty on the Functioning of the European Union-Part Three: Union Policies and Internal Actions-Title V: Area Of Freedom, Security And Justice-Chapter 4: Judicial cooperation in criminal matters-(ex Article 31 TEU), Official Journal 115, 09/05/2008 P. 0080 0081 .
} 


\section{Conclusions}

The argumentation presented above leads to the following conclusions:

1. The interpretation of Article 2 (2) of the FD EAW has to be done taking into account the international and European (not domestic) regulations; only in this way, it is possible to indicate one universal meaning of the UE law.

2. Both Issuing and Surrendering State are entitled to verify the grounds for omitting the requirement of double criminality, described in Article 2 (2) of the FD EAW.

3. De lege lata, there is no possibility of prosecuting designer drug crimes with the usage of the simple variant of the EAW procedure; the Article 2(2) of the FD EAW does not refer to the category of designer drugs; such category is not overlapped by neither 'narcotic drugs' nor 'psychotropic substances', which are mentioned in the above Article as a constituent element of a crime.

Acknowledgements This article was written as part of the research project 'Methods of implementation of international norms into domestic substantive criminal law. Dogmatic and theoretical analysis'. funded by the National Center for Science under Decision DEC-2018/31/D/HS5/01689.

Open Access This article is licensed under a Creative Commons Attribution 4.0 International License, which permits use, sharing, adaptation, distribution and reproduction in any medium or format, as long as you give appropriate credit to the original author(s) and the source, provide a link to the Creative Commons licence, and indicate if changes were made. The images or other third party material in this article are included in the article's Creative Commons licence, unless indicated otherwise in a credit line to the material. If material is not included in the article's Creative Commons licence and your intended use is not permitted by statutory regulation or exceeds the permitted use, you will need to obtain permission directly from the copyright holder. To view a copy of this licence, visit http://creativecommons.org/licenses/by/4.0/.

\section{References}

Ambos, K. (2005). Is a development of a common substantive criminal law for europe possible? Some preliminary reflections. Maastricht Journal of European and Comparative Law, 12, 173-191

Ambos, K. (2018). European criminal law. Cambridge University Press.

Bapuly, B. (2009). The European arrest warrant under constitutional attack. Vienna Online Journal on International Constitutional Law, 3, 4-26

Blekxtoon, R., \& van Ballegooij, W. (Eds.). (2005). Handbook on the European arrest warrant. Asser Press.

Braum, S. (2018). The CarlesPuigdemont case: Europe's criminal law in the crisis of confidence. German Law Journal, 19, 1349-1358

Case law by the Court of Justice of the European Union on the European Arrest Warrant. Criminal justice across border, Eurojust, 15 March 2020, source: http://www.eurojust.europa.eu/doclibrary/Euroj ust-framework/caselawanalysis/Case \%20law\%20by \%20the\%20Court\%20of\%20Justice\%20of\%20the\% 20European\%20Union\%20on\%20the\%20European\%20Arrest\%20Warrant\%20(March\%202020)/202003_Case-law-by-CJEU-on-EAW_EN.pdf. Access 14 July 2020.

Colson, R., \& Field, S. (Eds.). (2016). EU criminal justice and the challenges of diversity: Legal cultures in the area of freedom, security and justice. Cambridge University Press.

Council Framework Decision 2004/757/JHA of 25 October 2004 laying down minimum provisions on the constituent elements of criminal acts and penalties in the field of illicit drug trafficking.

Coutts, A. (1984). Double criminality. The Journal of Criminal Law, 48, 93-101

Directive (EU) 2017/2103 of the European Parliament and of the Council of 15 November 2017 amending Council Framework Decision 2004/757/JHA in order to include new psychoactive substances in the definition of 'drug' and repealing Council Decision 2005/387/JHA. 
European Commission. (2017). Handbook on how to issue and execute a European arrest warrant, Commission Notice of 28.9.2017. European Commission.

Fennelly, N. (2007). The European arrest warrant: Recent developments. ERA Forum, 8, 519-534

Fletcher, M., Lööf, R., \& Gilmore, B. (2008). EU criminal law and justice. Edward Elgar.

Gallant, K. (2009). The principle of legality in international and comparative criminal law. Cambridge University Press.

Gardocki, L. (1993). Double criminality in extradition law. Israeli Law Review, 22, 288-296

Geyer, F. (2007). European arrest warrant: Advocatenvoor de Wereld VZW v. Leden van de Ministerraad: Court of Justice of the European Communities, Judgment of 3 May 2007, Case C-303/05". European Constitutional Law Review, 4, 149-161

Gilmore, B. (2002). The EU framework decision on the European arrest warrant: An overview from the perspective of international criminal law. ERA Forum, 3, 144-47

Grundza case, C-289/15, ECLI:EU:C:2017:4. Judgment of the Court of Justice of od 11 January 2017.

Heard, C., \& Mansell, D. (2011). The European arrest warrant: The role of judges when human rights are at risk. New Journal of European Criminal Law, 2, 133-147

Herlin-Karnell, E. (2012). The constitutional dimension of European criminal law. Haart Publishing.

Herlin-Karnell, E. (2016). The challenges of EU enforcement and elements of criminal law theory: On sanctions and value in contemporary 'freedom, security and justice' law. Yearbook of European Law, 35, 291-317

Hudson, M. O. (1934). The factor case and double criminality in extradition. American Journal of International Law, 28, 274-306

Jareborg, N. (Ed.). (1989). Double criminality. Studies in international criminal law. Iustut.

Kettunen, M. (2020). Legitimizing European criminal law. Justification and restrictions. Springer.

Klimek, L. (2015). European arrest warrant. Springer.

Klimek, L. (2017). Mutual recognition of judicial decisions in European criminal law. Springer.

Lagodny, O. (2005). Possible ways to reduce the double criminality requirement: From double criminality to double prohibition, European Committee On Crime Problems (CDPC), PC-TJ, https://rm.coe. int/1680076ea0. Accessed 29 Apr 2021

Mackarel, M. (2007). The European arrest warrant - the early years: Implementing and using the warrant. European Journal of Criminal Law and Criminal Justice, 15, 37-65

Mancano, L. (2016). The right to liberty in european union law and mutual recognition in criminal matters. Cambridge Yearbook of European Legal Studies, 18, 215-238

Mansell, D. (2012). The European arrest warrant and defence rights. European Criminal Law Review, 2, $36-46$

Mitsilegas, V. (2009). EU criminal law. Hart Publishing.

Mullan G. (1997). The concept of double criminality in the context of extraterritorial crimes. Criminal Law Review, (Jan), 17-29.

Nohlen, N. (2008). Germany: The European arrest warrant case. International Journal of Constitutional Law, 6, 153-161

Öberg, J. (2020). Trust in the law? Mutual recognition as a justification to domestic criminal procedure. European Constitutional Law Review, 16, 33-62

Ouwerkerk, J. (2018). Balancing mutual trust and fundamental rights protection in the context of the European Arrest Warrant. What role for the gravity of the underlying offence in cjeu case law? European Journal of Crime, Criminal Law and Criminal Justice, 26, 103-109

Perignon, I., \& Dauce, C. (2007). The European Arrest Warrant: a growing sucess story. ERA Forum, 8, 203-214

Peristeridou, C. (2015). The Principle of legality in European criminal law. Intersentia.

Plachta, M. (2003). European arrest warrant: Revolution in extradition? European Journal of Crime, Criminal Law and Criminal Justice, 11, 178-194

Presidency conclusions. (2001). Laeken, European Council Meeting in Laeken, 14 and 15 December 2001. Source: https://www.consilium.europa.eu/media/20950/68827.pdf.

Quattrocolo S., Ruggeri, S. eds. (2019) Personal participation in criminal proceedings. A comparative study of participatory safeguards and in absentia Trials in Europe. Cham: Springer

Ralli, E. (2017). The principle of mutual recognition based on mutual trust and the respect for fundamental rights: The case of the framework decision on the European Arrest Warrant. European Law Institute, Annual Conference and General Assembly. https://www.europeanlawinstitute.eu/filea dmin/user_upload/p_eli/YLA_Award/Submission_ELI_Young_Lawyers_Award_Evgenia_Ralli_ 2017.pdf. Accessed 29 Apr 2021

Report. (2011). The Commission on the implementation since 2007 of the European Arrest Warrant - Press Release IP/11/454. Source: https://europa.eu/rapid/press-release_IP-11-454_en.htm?locale=en. 
Report. (2002). The Commission to the European Parliament and the Council on the implementation of Council Framework Decision of 13 June 2002 on the European Arrest Warrant and the surrender procedures between Member States of of 2 July 2020, 5754/EU XXVIV.

Sarmieto, D. (2008). European Union: The European arrest warrant and the quest for constitutional coherence. International Journal of Constitutional Law, 6, 171-183

Spencer, J. H. (2004). The European arrest warrant. Cambridge Yearbook of European Legal Studies, 6, 201-217

Stackhouse, T. P. (2012). Regulators in Wackyland: Capturing the last of the designer drugs. Arizona Law Review, 54, 1105

The Convention on Psychotropic Substances of 1971 signed in Vienna, Austria.

The Single Convention on Narcotic Drugs, 1961, as amended by the 1972 Protocol amending the Single Convention on Narcotic Drugs, 1961.

The United Nations Convention against Illicit Traffic in Narcotic Drugs and Psychotropic Substances, Vienna, 20 December 1988.

van Rossem, R. (2009). Interaction between EU law and international law in the light of Intertanko and Kadi: The dilemma of norms binding the member states but not the community. Netherlands Yearbook of International Law, (XL), 183-227.

van Sliedregt, E. (2007). The European arrest warrant: Between trust, democracy and the rule of law. European Constitutional Law Review, 3, 244-252

van den Wyngaert, C. (1989). Double criminality as a requirement to jurisdiction. In N. Jareborg (Ed.), Double criminality. Studies in international criminal law. (pp. 43-56). Iustut.

Vierucci, L. (2004). The European arrest warrant an additional tool for prosecuting ICC crimes. Journal of International Criminal Justice, 2, 275

Zając, D. (2019). The method of interpretation of penal norms in the international context. KIPK.

Ziegler, K. (2015). The relationship between EU law and international law. University of Leicester School of Law Research Paper, No. 15-04.

Publisher's Note Springer Nature remains neutral with regard to jurisdictional claims in published maps and institutional affiliations. 